\title{
WHAT DRIVES THE CHANGES IN THE GULF OIL MONARCHIES?
}

Nikola Kjurchiski

Russian Presidential Academy of National Economy and Public Administration (RANEPA) Centre for Resource Economics at RANEPA

The article identifies four main events driving the current changes in the Persian Gulf oil monarchies. Located in a troubled and unstable region of the Middle East with the oil prices declining after the events of the "Arab spring" and election of Donald Trump as president of the United States, Gulf oil monarchies are under pressure from inside and outside to undergo significant changes. As a consequence, validity of the theory of «monarchical exclusiveness» is called into question. The political elites in the monarchies recognize the need to depart from the status quo, although the phenomenon of the «king's dilemma» is still present there. The author argues that the monarchy should undergo conservative liberalization. To avoid political destabilization they should apply a gradual, evolutionary approach to liberalization providing their societies with enough time to adapt to new developments. Along with the gradual liberalisation process there is also need in institutional development to make institutions stronger and more independent.

Key words: monarchies of the Persian Gulf, monarchical exclusiveness, changes, conservative liberalization. 
The Middle East has always been one of the hottest spots on the planet with millennial conflicts raging between multiple parties in the region. The area between the Jordan River and the Mediterranean (corresponding today to the modern state of Israel and the Palestinian territories of the Gaza strip and the West Bank of Jordan River) is regarded as "the Holy Land" by the three major monotheistic religions: Christianity, Islam and Judaism, as well as several other communities, including Druze and Bahai [6]. This is the place where various cultures and religions intertwine often with opposing views on the political and economic organization, and all of them claim ownership of the land. The differences in culture and religious beliefs are not the main cause of the conflict, rather it is the battle for earth, which is a solid basis for long-lasting disputes.

In order to understand the contemporary conflicts in the Middle East we need to look back to 1947 when under the auspices of the United Nations the state of Israel was created and decision taken to establish the state for the Palestinians. The Arabs were to receive $43 \%$ of the land, while the Jews the rest $57 \%$. Both States were going to create an economic Union, whilst the Holy City of Jerusalem would be administrated by the United Nations [16]. Arab states objected the division of Palestine and rejected the Israel's existence. Since then military conflicts have become almost a routine between the state of Israel and the Arab world. These conflicts have also a religious dimension: on the one hand, the state of Israel, where the dominant religion is Judaism, and on the other hand states with Muslim domination. However, the situation is more complicated because at the same time Muslim countries are also divided between the Shia dominated Republic of Iran and the Sunni Arab countries (mainly the Gulf Arab oil monarchies). In addition to the historical background of the problem, there are other important factors.

The Middle East has the largest proven oil and gas reserves in the world $-47.3 \%$ of the total proved oil reserves and $42.8 \%$ of the total proved gas reserves. The largest oil producers are also concentrated there, producing $32.4 \%$ of the total production of oil and $17.4 \%$ of the total gas production ${ }^{1}$. The Middle East region is a bridge between East and West with pivotal trade and energy routes passing through making the region a critical area of concern on the world stage. Given the region's history and contemporary circumstances, immense cooperation efforts and political will are required in order to establish sustainable peace and development.

The ruling elite in the Gulf oil monarchies recognize the need for change. This is evident from their planning documents, called «Visions»². Almost all of the Gulf oil

\footnotetext{
1 BP Statistical Review of World Energy. June 2016. pp. 6, 8, 20, 22. [Электронный ресурc]. URL: http://www.bp.com/ content/dam/bp/pdf/energy-economics/statistical-review-2016/bp-statistical-review-of-world-energy-2016-full-report. pdf (дата обращения: 01.04.2017).

2 Realizing Qatar National Vision 2030. The Right to Development. Qatar's Fourth National Human Development Report. 2015. [Электронный ресурс]. URL: http://hdr.undp.org/sites/default/files/qatar_nhdr4_english_15june2015.pdf (дата обращения: 01.04.2017); UAE Vision 2021. United in Ambition and Determination. [Электронный ресурc]. URL: https:// www.vision2021.ae/sites/default/files/uae-vision2021-brochure-english.pdf(датаобращения:01.04.2017);BahrainVision 2030. 2013. [Электронный ресурc]. URL: http://www.bahrainedb.com/en/EDBDocuments/EDB-Vision-2030-May-2013. pdf (дата обращения: 01.04.2017); Oman's Ninth Five-Year Development Plan (2016-2020). [Электронный ресурс]. URL: http://www.marketstoday.net/includes/download.php?file=rr_18012016114554.pdf\&lang=en\&s=4464\&m=research (дата обращения: 01.04.2017).
} 
monarchies have their Visions of the future. For instance, the Saudi's deputy crown prince Mohammed bin Salman has announced the development strategy of Saudi Arabia in the post-oil era in an interview with Al-Arabiya under the title "Saudi Arabia's Vision 2030" 3 . These documents provide a good research material for assessing the future course of regional policy.

The Gulf oil monarchies (Saudi Arabia, UAE, Qatar, Kuwait, Oman and Bahrain) used to be the most stable political regimes in the region. However, this dogma of «monarchical exclusiveness» was shattered during the past half-decade. It suggests that the Gulf monarchies are stable and steady in extremely unstable and volatile region because they enjoy stable and resilient political regimes [3, p. 2].

Alvarez et al. identified two types of political regimes: democratic and authoritarian [2]. In their view, democratic regimes meet at least three following conditions. First, there should be a possibility for an incumbent party to lose elections (ex-ante uncertainty). Second, the winner of elections should be allowed to obtain political power. The results of the election should be irreversible, if we consider the elections free and fair (ex-post irreversible). Third, the elections must be a recurring process in democratic regimes, which makes all results of the elections temporary, leaving the possibility of winning and losing the next elections. To define authoritarian regimes, Alvarez et al. use false dichotomy - all regimes that are not democracies are authoritarian, recognize different types of authoritarian regimes [2, p. 5-6]. All six Gulf oil countries are authoritarian hereditary monarchies. According to Sean Yom and Gregory Gause, monarchy is defined as a regime led by a hereditary sovereign who may hold varying degrees of power $[18$, p. $76 ; 19]$.

The events in the global geopolitical arena over the past five years have become a serious challenge for political elites in the oil monarchies of the Persian Gulf. Despite the fact that these monarchies are much more stable in comparison with the republics of the region, the ruling elites of monarchies are also called upon to react to events that influence their economic, social and political systems. Although the Arab Republic or the Jamahiriya (in the case of Libya) contained the prefix "republic" in their names, in fact, all these countries are more or less authoritarian. According to the latest democracy index of the Economist Intelligence Unit, most countries in the Middle East are defined as authoritarian, with the exception of Turkey, Lebanon, Palestine and Iraq, which are defined as hybrid regimes, and Israel as an incorrect democracy ${ }^{4}$. The general picture of the classification of these regimes is not black and white, because in all of them one can find democratic institutions to some extent. They demonstrate a various combinations of autocratic and democratic institutions. Almaz, Linz and Lip-

\footnotetext{
3 Full Transcript of Prince Mohammed bin Salman's Al Arabiya interview. 2016. [Электронный ресурc]. URL: http:// english.alarabiya.net/en/media/inside-the-newsroom/2016/04/25/Full-Transcript-of-Prince-Mohammed-bin-Salman-sAl-Arabiya-interview.html (дата обращения: 01.04.2017); Full Text of Saudi Arabia's Vision 2030. Saudi Gazette. 2016. [Электронный ресурс]. URL: http://saudigazette.com.sa/saudi-arabia/full-text-saudi-arabias-vision-2030/ (дата обращения: 01.04.2017).

4 The Economist Intelligence Unit. Democracy Index 2015. Democracy in an Age of Anxiety. Pр. 5-8. [Электронный реcypc]. URL: http://www.yabiladi.com/img/content/EIU-Democracy-Index-2015.pdf (дата обращения: 01.04.2017).
} 
set call these regimes "semi-democracies" [9, p. 25] or the hybrid regimes described below, [10] where the effective power of elected officials is very limited or competition in a political party is limited, or the freedom and fairness of elections are highly compromised meaning that the election results are significantly different from popular preferences.

It is important to distinguish democratization and liberalization and acknowledge that the oil monarchies of the Persian Gulf do not need to be democratized, at least for the time being, but they need liberalization. The countries of the Persian Gulf do not seem to be ready for democracy. Instead a revolutionary approach should be applied in the process of liberalization, gradually moving towards reforms so that the society has time to adapt to new developments. This process might be called "conservative liberalization", because it takes into account the cultural and traditional specificity of these societies. In parallel with conservative liberalization, institutional development is crucial for the strengthening of institutions. Thus, together they would ensure sustainable development of the countries.

This study singles out four important events that have occurred over the past decade, forming a new reality in monarchies: 1) the events of the "Arab spring"; 2) constant instability in the Middle East; 3) the rapid decline in oil prices and 4) the election of Donald J. Trump as President of the United States.

Events of the "Arab spring". In chronological order, it all began with the uprising of the "Arab spring" that started in Tunis in 2010 with questioning the authority of President Ben Ali, who had been in power for many years. The wave of unrest spread throughout the region, bringing turmoil to the places where similar demands for the liberation of the political system, more representative and transparent elections and visible changes in the political behavior of the elites were present. The oil monarchies of the Persian Gulf demonstrated an unprecedented level of political stability before and after the "Arab spring".

In his study Bona [7, p. 275] identified three elements that should be taken into account in analyzing the authoritarian stability of the Gulf countries, namely, cultural, political and social structures and institutions. Monarchy as a form of government is closely intertwined with national culture and tradition. As for the political and social structures of the oil monarchies it was established that political elites allocate oil and gas rent among the population in order to increase their material and social satisfaction and make them uninterested in politics. In other words, the governments establish strong relations with their citizens by redistributing among them income from oil and gas rent in order to maintain high authority [5].

Huntington believes that the main problem in monarchies is caused by the "royal dilemma" [11, p. 60]. "King's dilemma" implies that kings suffer from changes when some kind of reform is being implemented. Any change can lead to a process that is likely to damage the king's power, but on the other hand, the status quo is not sustainable in the long run. Most monarchial governors usually decide to keep the status quo as long as possible hoping that people will remain calm and indifferent. 
Despite the small differences between monarchies and republics in the Middle East, especially before the "Arab spring", monarchies have a higher level of political liberalization $[4 ; 13 ; 15 ; 17]$. But it is not only the levels of political liberalization that differ, levels of economic liberalization are even more different. Oil monarchies of the Persian Gulf are reminiscent of Western developed economies when it comes to liberalizing the economy. Today the oil monarchs of the Persian Gulf are financial and transport centers of the region attracting foreign direct investment due to their liberal economic system and zero taxation policy. Strong ownership rights give investors the exclusive right to use their resources at their own discretion and take full account of all the benefits and costs associated with their judgments.

However, after the "Arab spring" the perception of people living in the oil monarchies of the Persian Gulf have changed. They realized that, although they live in authoritarian monarchies, they can still question their governments. Despite the absence of direct mechanisms to hold governments accountable, there is always the opportunity to go out and protest. The ruling monarchy also knew this and understood that these changes are important.

Constant instability and volatility in the Middle East. Instability is a serious problem in the Middle East and the Persian Gulf region. War and terrorism are not the only problems facing the monarchies of the Persian Gulf. A high level of dependence on oil and gas resources makes the monarchies sensitive to commodity prices. As prices decline it significantly reduces the ability of the monarchy to keep the same income and rent for the population, which the government uses as a mechanism to preserve its power and ensure the political tranquility and silence of citizens. The main problem is related to recent changes in demography $[8, \mathrm{c} .10]$. Population growth occurring now in monarchies does not allow to provide the same social benefits as before. With the growth of population the reserves of wealth obtained from oil can turn into nothing [8, p. 10].

In the short term the monarchies of the Persian Gulf hold large amount of reserves, so cutting state spending right now is not necessary, and at the moment they are not doing it [14]. Reducing spending can cause great damage to monarchies. This would significantly increase the threat of new uprisings to exert pressure on the ruling elites to ensure better living conditions.

The phenomenon of "youth bulge" is perceived as one of the main factors that have the greatest impact on the instability of the monarchical countries of the Persian Gulf. The rapid demographic change among young people is caused by the reduction in mortality rate [1]. Under the pressure of low oil prices all monarchies are subject to spending cuts to balance their budgets. One of the characteristics of all the oil monarchies of the Persian Gulf is the large state sector. The large public sector model is an obsolete and very expensive model for financing. So most citizens are concerned with the large state sector. Citizens are not motivated to start looking for work outside the public sector.

Most new jobs are in the public sector, despite the fact that very few new jobs have been created. This makes the public sector extremely unsustainable in the long term. 
On the other hand, monarchies can turn "youth bulges" into their biggest economic resource, since most of the young people are going to universities and are looking for better job and career opportunities [1]. Investment in education, which has already begun, and the creation of new jobs, mainly in the private sector, are crucial.

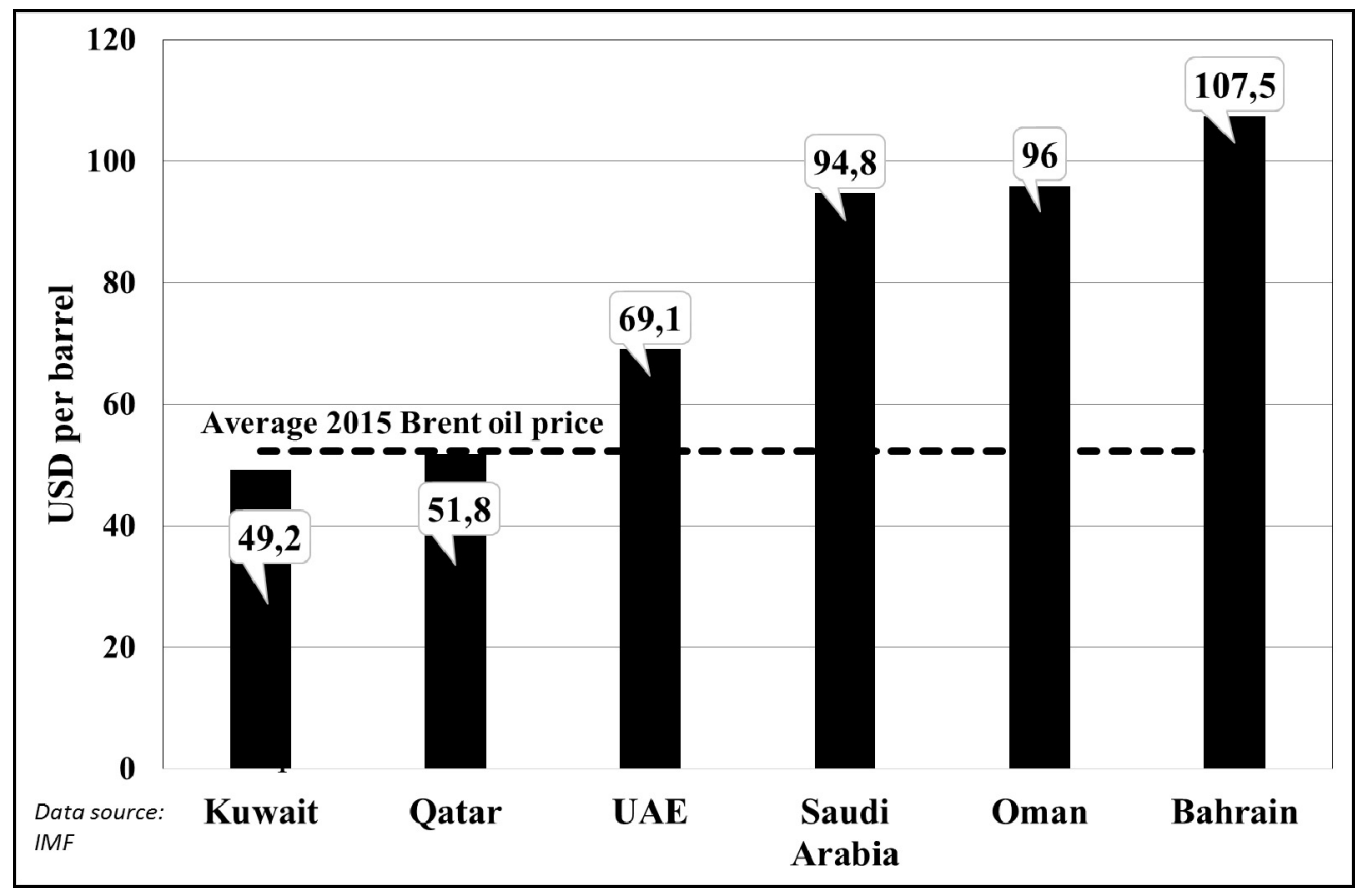

Figure 1. Chart of the 2015 Fiscal Breakeven Oil Price (Oil price at which the fiscal balance is 0 )

The fall in the price of oil. Oil monarchies of the Persian Gulf are a resource economy. The oil sector dominates the economy and oil rents are the largest source of public finance. Consequently, some monarchies pursue zero-tax policy (Bahrain and the United Arab Emirates) $)^{5}$. However, there are monarchies of the Persian Gulf, which are diversifying their economies, for example, the Emirate of Dubai, where only $1.8 \%$ of GDP in 2015 falls on mining ${ }^{6}$. The royal families monopolized the oil resources in order to maintain control and power. It is becoming increasingly difficult to maintain costly and reliable government management at low oil prices.

Figure 1 shows a chart with projected oil prices for each of the oil monopolies in the Persian Gulf for 2015, at which the budget balance will be 0 versus the average price of Brent crude in 2015. The diagram shows that the UAE, Saudi Arabia, Oman and Bahrain have an unbalanced budget, deviating from the average price of Brent

\footnotetext{
5 Ernst \& Young. Worldwide Corporate Tax Guide 2016. Pp. 122, 1507. [Электронный ресурc]. URL: http://www.ey.com/ Publication/vwLUAssets/Worldwide_Corporate_Tax_Guide_2016/\$FILE/2016\%20Worldwide\%20Corporate\%20Tax\%20 Guide.pdf (дата обращения: 01.04.2017).

6 Dubai Statistics Centre. Gross Domestic Product at Constant Prices 2015-2014. [Электронный ресурc]. URL: https:// www.dsc.gov.ae/en-us/Themes/Pages/National-Accounts.aspx?Theme=24 (дата обращения: 01.04.2017).
} 
crude in 2015: \$ 16.75 per barrel, \$ 42.45 per barrel, 43, US \$ 65 per barrel and US \$ 55.15 / bbl., respectively ${ }^{7}$.

Election of Donald J. Trump as President of the United States of America. The United States is the largest Western ally for the oil monarchies, but after the 2016 presidential elections the relations between US and the oil monarchies seem to be deteriorating especially in case of Saudi Arabia. Although relations during Obama's administration were not perfect, Trump's aggressive rhetoric increases various concerns even more. During presidential campaign he said that the US should block all oil imports from Saudi Arabia, and that all the allies of the United States should pay for US military protection, stressing that Saudi Arabia is one of them.

Mishaal Al Gergawi speaking at the Gaidar forum in Moscow said that Obama had done a great service to the Gulf countries, making them realize that they should not expect too much from the United States. The countries of the Persian Gulf should think about how to improve their security system themselves. There are various ways to do this, including investments in technology, cybersecurity and special forces. As for Trump, Al Gergawi said that he did not expect radical changes, as Trump suggested in his pre-election rhetoric. He believes that Trump will manage the country as he manages his business by choosing 3 or 4 large projects that will make him famous as a successful leader, but not expecting it to happen in the Middle East or, more precisely, in the monarchies of the Persian Gulf8.

President Trump before elections and Trump after the elections are different politicians. During the campaign Trump had to mobilize support, rather than provide a comprehensive and in-depth program and plans for his presidency. The media never took Trump seriously, but they always took him literally, while his supporters take him seriously, but not literally. Trump could not ban the import of oil from Saudi Arabia, as the US imports more than 6 million barrels of oil per day. Saudi Arabia holds 11\% of the world's oil market, which makes it almost impossible for the United States to prohibit the import of Saudi oil into the United States. Nevertheless, there is still a high probability that Trump will further cool relations between the oil monarchies of the Persian Gulf and the United States. It can put more pressure on rulers in monarchies to cope with situations on their own. Another question is how people living there can accept this. Most of them would feel abandoned from its biggest ally blaming their own leaders for it.

Given the recent events, the oil monarchies of the Persian Gulf are in an unstable and defensive position. The main challenges for the oil monarchies are creation of new jobs, modernization of the education system to make it more inclusive, as well as attempts to cope with the fall in oil prices and balance the budget. The four outlined above events pose a serious challenge for governments, but at the same time may be

\footnotetext{
7 IMF Regional Economic Outlook: Middle East and Central Asia; April 2016. P: 7. [Электронный ресурc]. URL: https:// www.imf.org/external/pubs/ft/reo/2016/mcd/eng/pdf/mreo0416st.pdf (дата обращения: 01.04.2017).

$8 \mathrm{Al}$ Gergawi M. Presentation at the Gaidar Forum on the session: Global Transformation in the Mirror of Historical Sociology // Russian Presidential Academy of National Economy and Public Administration. 2017. [Электронный ресурс]. URL: http://asa-comparative-historical.org/newsletter/Trajectories_Winter_2017.pdf (дата обращения: 01.04.2017).
} 
an opportunity to brake the status quo and take steps to gradually liberalize political regimes, thereby ensuring more sustainable development and improving living conditions for their citizens.

These events can be a turning point not only for the monarchies, but also for the region. Political elites recognize that all sectors of society present opportunities for improvement. Socially, reforms could be directed at empowerment of women and the expansion of human rights to accelerate social development through affordable health care, education and jobs. In political terms there is a need in creating more inclusive political institutions encouraging increasing participation of ordinary citizens in political life of their countries. This can have a positive impact on citizens, making them feel part of their country and at the same time politically educating them. At the moment conservative values prevail in public opinion, meaning that political empowerment of citizens should take a gradual pace otherwise liberalization processes might be undermined and reversed.

It is important that people come to power through elections, thereby gaining legitimacy from all the citizens having the right to vote. In this case, the ruling elite will also receive a rational-legal type of legitimation, notwithstanding the legitimacy obtained only by divine law [12]. However, these steps should be taken lightly, and changes must occur gradually, so citizens can use them in a new environment and easily adopt them in accordance with the previously defined process of conservative liberalization.

\section{References}

1. Al Munajjed M., Sabbagh K. Youth in GCC countries: meeting the challenge. Insight Ideation Center. Booz \& Company Inc., 2011. 77 p.

2. Alvarez M., Cheibub J.A., Limongi F., Przeworski A. Classifying Political Regimes. Studies in Comparative International Development, 1996, vol. 31, no. 2, pp. 3-36.

3. Anderson L. Absolutism and the Resilience of Monarchy in the Middle East. Political Science Quarterly, 1991, vol. 106, no 1, pp. 1-15.

4. Anderson L. Middle East Monarchies: the Challenge of Modernity. Ed. by J. Kostiner. Boulder, Lynne Rienner Publ., 2000. 241 p.

5. Barari H.A. The Persistence of Autocracy: Jordan, Morocco and the Gulf. Middle East Critique, 2015, vol. 24, no. 1, pp. 99-111.

6. Beinin J. A Primer on Palestine, Israel and the ArabIsraeli Conflict. Middle East Research and Information Project, 2014. Available at: http://lokayat.org. in/books/palestine.pdf (Accessed: 01.04.2017).

7. Bona M. Asian Values and Gulf Monarchical Exceptionalism. Springer: East Asia, 2015, vol. 32, no 3, pp. 273-287.

8. Cordesman A.H. Stability and Instability in the Gulf Region in 2016: A Strategic Net Assess- ment. Center for Strategic and International Studies (CSIS), 2016. Available at: https:// csis-prod.s3.amazonaws.com/s3fs-public/ publication/160615_Gulf_Stability_Instability. pdf (accessed: 01.04.2017).

9. Diamond L.J. Thinking About Hybrid Regimes. Journal of Democracy, 2002, vol. 13, no. 2, pp. 21 35.

10. Finer S.E. Comparative Government. London, Penguin Press Publ., 1970. 640 p.

11. Huntington S.P. Political Order in Changing Societies. London, Yale University Press Publ. 263 p.

12. Kjurchiski N. Elections as Contemporary Mechanism for Legitimation of the Gulf Oil Monarchies in the Post Arab Spring Era. Communicology Journal, 2016, vol. 4, no. 5, pp. 33-39.

13. Lucas R.E. Monarchical Authoritarianism: Survival and Political Liberalization in a Middle Eastern Regime Type. International Journal of Middle East Studies, 2004, vol. 36, no 1. pp. 103 119.

14. Martini J., Wasser B., Kaye D.D., Egel D., Ogletree C. The Outlook for Arab Gulf Cooperation. Santa-Monica, RAND Corporation Publ., 2016. $82 \mathrm{p}$. 
15. Menaldo V. The Middle East and North Africa's Resilient Monarchs. The Journal of Politics, 2012, vol. 74, no. 03, pp. 707-722.

16. Richman S.L. "Ancient History": U.S. Conduct in the Middle East Since World War II and the Folly of Intervention. Cato Policy Analysis, 1991, no. 159. CATO Institute. Available at: https://object. cato.org/sites/cato.org/files/pubs/pdf/pa159.pdf (accessed: 1/04/2017)

17. Spinks T. The Status of Democracy and Human
Rights in the Middle East: Does Regime Type Make a Difference? Democratization, 2008, vol. 15, no 2, pp. 321-341.

18. Yom S.L. Resilient Royals: How Arab Monarchies Hang on. Journal of Democracy, 2012, vol. 23, no. 4, pp. 74-88.

19. Yom S.L. The Survival of the Arab Monarchies. November 2012. Available at: http://foreignpolicy.com/2012/11/12/the-survival-of-the-arabmonarchies (accessed: 01.04.2017).

\section{About the author:}

Nikola Kjurchiski - PhD student in Political Science at the Russian Presidential Academy of National Economy and Public Administration (RANEPA), Research fellow of the Centre for Resource Economics at RANEPA. 119571, Prospect Vernadskogo 82/5, Moscow, Russian Federation. E-mail: kjurchiskin@gmail.com.

\section{ЧТО ДВИЖЕТ ИЗМЕНЕНИЯМИ В НЕФТЯНЫХ МОНАРХИЯХ ПЕРСИДСКОГО ЗАЛИВА?}

Никола Кюрчиски

DOI 10.24833/2071-8160-2017-5-56-199-208

Российская академия народного хозяйства и государственной службы при Президенте Российской Федерации (РАНХиГС). Центр сырьевой экономики (РАНХиГС)

В статье определены четыре основных события, которые произошли за последние полтора десятилетия и обусловили нынешние изменения в нефтяных монархиях Персидского залива. Прежде всего, это события «арабской весны» и сохраняющаяся нестабильность на Ближнем Востоке, а также стремительное падение цен на нефть и избрание Дональда Трампа президентом Соединённых Штатов Америки.

Таким образом, находясь в и без того тревожных и нестабильных условиях, нефтяные монархии Персидского залива сталкиваются как с внутренними, так и с внешними вызовами, для ответа на которые требуются значительные реформы.

Как следствие, ставится под сомнение обоснованность теории «монархической исключительности». Политические элиты в монархиях признают необходимость отступления от статус-кво, хотя явление «королевской дилеммы» до сих пор присутствует в авторитарном мире.

Автор доказывает, что для монархий оптимален путь консервативной либерализации. Чтобы избежать политической дестабилизации, они должны проводить либеральные реформы постепенно, предоставляя своим обществам достаточно времени для адаптации к новым условиям. Наряду с процессом постепенной либерализации необходимо также институциональное развитие для создания сильных и независимых институтов.

Ключевые слова: монархии Персидского залива, «монархическая исключительность», изменения, консервативная либерализация. 


\section{Список литературы}

1. Al Munajjed M., Sabbagh K. Youth in GCC countries: meeting the challenge / Insight Ideation Center. Booz \& Company Inc., 2011. 77 p.

2. Alvarez M. Cheibub J.A., Limongi F., Przeworski A. Classifying Political Regimes // Studies in Comparative International Development. 1996. Vol. 31. No. 2. Pp. 3-36.

3. Anderson L. Absolutism and the Resilience of Monarchy in the Middle East // Political Science Quarterly. 1991. Vol. 106. No. 1. Pp. 1-15.

4. Anderson L. Middle East Monarchies: The Challenge of Modernity / ed. by J. Kostiner. Boulder: Lynne Rienner Publishers. 2000. 241 p.

5. Barari H.A. The Persistence of Autocracy: Jordan, Morocco and the Gulf // Middle East Critique. 2015. Vol. 24. No. 1. Pp. 99-111.

6. Beinin J. Palestine, Israel and the ArabIsraeli Conflict: a Primer. Middle East Research and Information Project. 2014. URL: http://lokayat.org.in/books/palestine.pdf (дата обращения: 01.04.2017).

7. Bona M. Asian Values and Gulf Monarchical Exceptionalism // Springer: East Asia. 2015. Vol. 32. No. 3. Pp. 273-287.

8. Cordesman A.H. Stability and Instability in the Gulf Region in 2016: A Strategic Net Assessment. Center for Strategic and International Studies (CSIS). 2016. URL: https://csis-prod.s3.amazonaws. com/s3fs-public/publication/160615_ Gulf_Stability_Instability.pdf (дата обращения: 01.04.2017).

9. Diamond L.J. Thinking About Hybrid Regimes // Journal of Democracy. 2002. Vol. 13. No. 2. Pp. 21-35.

10. Finer S.E. Comparative Government. London: Penguin Press, 1970. 640 p.
11. Huntington S.P. Political Order in Changing Societies. London: Yale University Press. 263 p.

12. Kjurchiski N. Elections as Contemporary Mechanism for Legitimation of the Gulf Oil Monarchies in the Post Arab Spring Era // Communicology Journal. 2016. Vol. 4. No. 5. Pp. 33-39.

13. Lucas R.E. Monarchical Authoritarianism: Survival and Political Liberalization in a Middle Eastern Regime Type // International Journal of Middle East Studies. 2004. Vol. 36. No. 1. Pp. 103-119.

14. Martini J., Wasser B., Kaye D.D., Egel D., Ogletree C. The Outlook for Arab Gulf Cooperation. Santa-Monica: RAND Corporation, 2016. 82 p.

15. Menaldo V. The Middle East and North Africa's Resilient Monarchs // The Journal of Politics. 2012. Vol. 74. No. 03. Pp. 707-722.

16. Richman S.L. "Ancient History": U.S. Conduct in the Middle East Since World War II and the Folly of Intervention. Cato Policy Analysis. No. 159, CATO Institute. 1991. URL: https://object.cato. org/sites/cato.org/files/pubs/pdf/pa159. pdf (accessed: 01.04.2017).

17. Spinks T. The Status of Democracy and Human Rightsvin the Middle East: Does Regime Type Make a Difference? // Democratization. 2008. Vol. 15. No. 2. Pp. 321-341.

18. Yom S.L. Resilient Royals: How Arab Monarchies Hang on // Journal of Democracy. 2012. Vol. 23. No. 4. Pp. 7488.

19. Yom S.L. The Survival of the Arab Monarchies. November 2012. URL: http:// foreignpolicy.com/2012/11/12/thesurvival-of-the-arab-monarchies/ (дата обращения: 01.04.2017).

\section{6 aвmopax:}

Никола Кюрчиски - аспирант, научный сотрудник Российской академии народного хозяйства игосударственной службыпри ПрезидентеРоссийскойФедерации (РАНХиГС), Центр сырьевой экономики (РАНХиГС). 119571, г. Москва, проспект Вернадского, 82, стр.1. E-mail: kjurchiskin@gmail.com. 